\title{
Plasma electrolyte concentration in food-deprived goats orally supplemented with potassium chloride
}

\author{
BY KJELL HOLTENIUS \\ Department of Animal Physiology, Swedish University of Agricultural Sciences, PO Box 7045, \\ S-750 07 Uppsala, Sweden
}

(Received 27 June 1989 - Accepted 5 February 1990)

\begin{abstract}
The aim of the present study was to investigate whether oral potassium supplementation during food deprivation could stimulate rumen electrolyte absorption and maintain plasma electrolyte concentration. Eight goats were subjected to food deprivation in combination with intrarumen loads of potassium chloride or, as a control, mannitol in a change-over design. In addition, four $\mathrm{KCl}$ - and four mannitoltreated goats were given an extra $\mathrm{KCl}$ load towards the end of the experiment. Food-deprived goats which were given $\mathrm{KCl}$ maintained their plasma concentration of $\mathrm{Na}$ and $\mathrm{Cl}$, while plasma $\mathrm{K}$ concentration increased from $3.6 \mathrm{~mm}$ to $4.4 \mathrm{~mm}$. In control goats receiving mannitol during food deprivation, the plasma concentration (mM) decreased from 144 to $140 \mathrm{for} \mathrm{Na}, 105$ to 100 for $\mathrm{Cl}$ and from 3.8 to 3.6 for $\mathrm{K}$, but concentrations were restored when these goats were given a load of $\mathrm{KCl}$. The plasma renin activity was suppressed in food-deprived goats receiving $\mathrm{KCl}$, while those given mannitol showed increased activity. It is suggested that the hyponatraemia which occurs in food-deprived ruminants is mainly caused by diminished $\mathrm{K}$ intake.
\end{abstract}

Electrolytes: Potassium chloride supplementation: Goat

Ruminants normally ingest large quantities of potassium with the food, while the sodium intake is smaller. During feeding and rumination, large volumes of saliva containing substantial amounts of $\mathrm{Na}$ and $\mathrm{K}$ enter the rumen (McDougall, 1948). Re-absorption of $\mathrm{Na}$ is necessary in order to maintain the plasma $\mathrm{Na}$ concentration and Dobson (1959) estimated that about $50 \%$ of the $\mathrm{Na}$ in saliva is re-absorbed from the rumen of sheep. It is a matter of controversy whether the rumen fluid concentration of $\mathrm{K}$ influences $\mathrm{Na}$ absorption. In vivo studies indicate that a high rumen concentration of $\mathrm{K}$ stimulates the absorption of $\mathrm{Na}$ from rumen to blood (Scott, 1967; Martens \& Hammer, 1981). However, in vitro studies indicate that the $\mathrm{Na}$-hydrogen exchange is the predominant system for $\mathrm{Na}$ absorption, and that $\mathrm{K}$ does not influence the $\mathrm{Na}$ absorption through the rumen epithelium (Strozyk, 1987; Martens \& Gäbel, 1988).

Food deprivation in small ruminants leads to hyponatraemic hypovolaemia which activates the renin-angiotensin-aldosterone system (RAAS) (Dahlborn \& Karlberg, 1986). In a subsequent study it was shown that the Na concentration of the rumen fluid increased, but that the K concentration decreased (Holtenius \& Dahlborn, $1990 \mathrm{~b}$ ). It was suggested that the $\mathrm{Na}$ absorptive capacity of the rumen became impaired during food deprivation, which caused the hyponatraemia and activation of the RAAS.

The aim of the present experiments was to investigate whether plasma and urine electrolytes, plasma volume, and the activity of the RAAS would remain unchanged during food deprivation if the goats were supplemented with $K$ into the rumen in amounts corresponding to that which they normally receive with their food. In control experiments mannitol was given to food-deprived goats. Mannitol is often used to increase the osmotic pressure of rumen fluid in absorption studies (Warner \& Stacy, 1977). It was also 
decided to study, at the end of the food-deprivation period, the effect of an intrarumen load of potassium chloride given both to goats which had received $\mathrm{KCl}$ and to those which had received mannitol during the deprivation period.

\section{MATERIALS AND METHODS}

\section{Animals}

Eight adult female goats of the Swedish domestic breed (body-weight 38 (SE 2.8) $\mathrm{kg}$ ) were used. They were kept in metabolism cages and given $500 \mathrm{~g}$ hay and $50 \mathrm{~g}$ concentrates including $3 \mathrm{~g}$ sodium chloride at each meal ( 08.00 and 16.00 hours) except during the fooddeprivation experiments. The hay contained $(\mathrm{g} / \mathrm{kg}): 870$ dry matter (DM), $8.7 \mathrm{MJ}$ metabolizable energy $(\mathrm{ME}) / \mathrm{kg}, 70$ digestible crude protein (nitrogen $\times 6.25 ; \mathrm{DCP}), 0.8 \mathrm{Na}$ and $18.4 \mathrm{~K}$. The concentrates contained $(\mathrm{g} / \mathrm{kg}) 900 \mathrm{DM}, 11.7 \mathrm{MJ} \mathrm{ME} / \mathrm{kg}, 140 \mathrm{DCP}$, $0.4 \mathrm{Na}$ and $9.6 \mathrm{~K}$. Water was available $\mathrm{ad}$ lib.

\section{Experimental procedures}

The eight goats were randomly divided into two groups. Both groups were subjected to two treatments in a change-over design: food deprivation either in combination with intrarumen loads of $\mathrm{KCl}$ ( $\mathrm{KCl}$ goats), or, as a control, food deprivation in combination with intrarumen loads of mannitol (mannitol goats). Mannitol was given in order to raise the osmotic pressure of the rumen fluid to the same level as the $\mathrm{KCl}$ goats. There was an interval of 1 week between experiments. Between experiments all goats were fed according to normal routines. The experimental routine is described in Fig. 1. Water intake and urinary excretion were measured during two periods each of $24 \mathrm{~h}$. On day 1 the goats were fed normally. On day 2 at 08.00 hours food residues, if any, were removed and no food was offered until 16.00 hours the following day (day 3), when the goats were given $500 \mathrm{~g}$ hay and $50 \mathrm{~g}$ concentrates. At normal feeding times ( 08.00 hours and 16.00 hours) when no feed was offered, $17 \mathrm{~g} \mathrm{KCl}(\mathrm{K} 9 \mathrm{~g})$ or $87 \mathrm{~g}$ mannitol dissolved in $350 \mathrm{ml}$ water were introduced into the rumen via a stomach tube. The osmolality of both solutions was $1 \cdot 3 \mathrm{osmol} / \mathrm{kg}$. The calculated increase of the rumen fluid osmolality was about 70 mosmol $/ \mathrm{kg}$ immediately after dosing, assuming a rumen fluid volume of 6 litres (Holtenius \& Björnhag, 1989). On day 3 at 10.00 hours a blood sample was taken from all animals and immediately thereafter an intrarumen load of 3 litres water at $39^{\circ}$, mixed with $50 \mu \mathrm{Ci}$ tritiated water (TOH), were given by stomach tube to two $\mathrm{KCl}$ goats and two mannitol goats from each group. After administration of the water load, blood samples for analysis of TOH activity in plasma were withdrawn every $10 \mathrm{~min}$ for $60 \mathrm{~min}$. At 11.00 hours all four goats were given an intrarumen load of $\mathrm{KCl}$ as described previously. Additional blood samples were collected according to Fig. 1.

\section{Analysis}

The TOH activity in plasma was measured in a scintillation counter (LKB 1217, Wallac Oy. Turku, Finland), and values were corrected for quenching. $\mathrm{Na}$ and $\mathrm{K}$ were determined by the ion-selective method (System E2A electrolyte analyser, Beckman Instruments Inc. Glenrothes, Scotland) and the Cl concentration was determined colorimetrically (CMT 10; Radiometer, Copenhagen, Denmark). The osmolality was determined by molar freezingpoint depression (VAO 1 osmometer; Roebeling, Berlin, Germany). Total plasma protein concentration (PP) was measured by refractometry. For determination of plasma renin activity (PRA) and plasma aldosterone concentration (PAC), blood was collected in prechilled tubes containing $\mathrm{K}_{3}$ EDTA and centrifuged at $4^{\circ}$. The plasma was separated and 


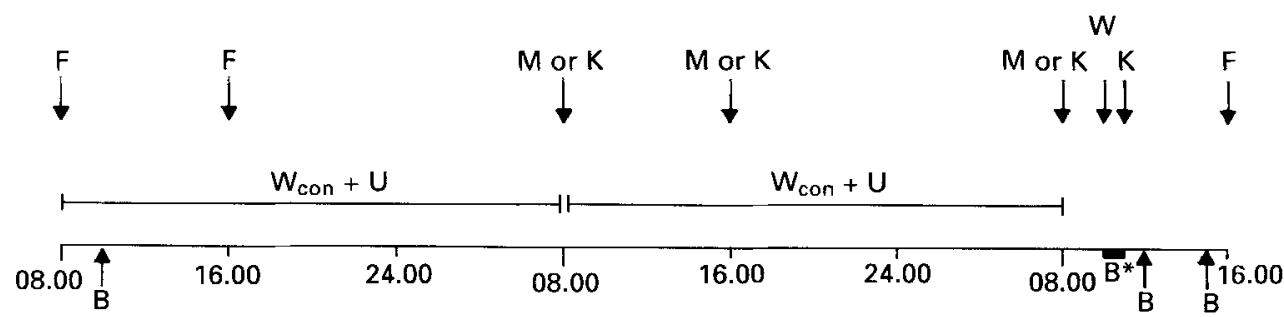

Day 1

Day 2

Day 3

Fig. 1. Experimental procedure. $F$, feeding; $U$, urine collection; $W_{c o n}$, water consumption measurements; $B$, blood sampling; $\mathrm{B}^{*}$, blood sampling every $10 \mathrm{~min} ; \mathrm{M}, \mathrm{K}$ and $\mathrm{W}$, intrarumen loads of mannitol, potassium chloride and water respectively.

stored at $-20^{\circ}$. PRA was determined by radioimmunoassay using an assay kit (Phadebas Angiotensin I test; Pharmacia Diagnostics, Uppsala). PAC was determined according to McKenzie \& Clements (1974).

\section{Calculations}

If the transfer of $\mathrm{TOH}$ from rumen to plasma follows first-order kinetics, the rate constant for the TOH transfer can be calculated according to the equation:

$$
A_{p 300}-A_{p t}=A_{p 300} \times e^{-k t}
$$

where $A_{p t}$ is the plasma TOH activity at time $t$ (samples were taken $10,20,30,40,50$, 60 and $300 \mathrm{~min}$ after the fluid load), $A_{p 300}$ is the equilibrated plasma TOH activity $300 \mathrm{~min}$ after the fluid load and $k$ is the rate constant for TOH transfer from rumen to plasma.

The back flow of TOH from plasma to rumen was not compensated for since the rumen TOH concentration was much higher than the plasma TOH concentration during the 60 min measurement period (K. Holtenius, unpublished results). The model was fitted to data with a microcomputer program (PCNONLIN, Statistical Consultants Inc. Edgewood, USA). Values are presented as means with their standard errors. The tests for significance were done by analysis of variance (general linear model; SAS Institute Inc., Cary, USA).

\section{RESULTS}

\section{Effects of $\mathrm{KCl}$ or mannitol treatment during food deprivation}

Water intake decreased from 2.6 litres/d and 2.2 litres/d (SE 0.19) to 0.9 litres/d and 0.8 litres/d (SE 0.22 ) for $\mathrm{KCl}$ goats and mannitol goats respectively, during food deprivation $(P<0.01 v$. control in each group). The urine excretion was 1.4 (SE 0.21$)$ litres/d for both treatments before food was withdrawn, and during food deprivation $\mathrm{KCl}$ goats excreted 1.7 litres/d and mannitol goats 1.0 litre/d (SE 0.34; the differences were not significant). Urinary $\mathrm{Na}$ and $\mathrm{Cl}$ excretions increased when the goats received the $\mathrm{KCl}$ solution. When mannitol was given neither $\mathrm{Na}$ nor $\mathrm{Cl}$ excretion changed significantly (Table 1 ). The $\mathrm{K}$ excretion did not change significantly when $\mathrm{KCl}$ was given, but decreased when the goats received mannitol (Table 1).

When the goats received $\mathrm{KCl}$ solutions the plasma $\mathrm{Na}$ and $\mathrm{Cl}$, osmolality and $\mathrm{PP}$ remained unchanged, while plasma $\mathrm{K}$ increased. In mannitol goats the plasma concentrations of $\mathrm{Na}, \mathrm{K}$ and $\mathrm{Cl}$, and the osmolality decreased while PP was not significantly affected (Table 2). 
Table 1. Effects of food deprivation in combination with intrarumen loads of mannitol or potassium chloride on urinary excretion of sodium, potassium and chloride $(\mathrm{mmol} / \mathrm{d})$ in goats $\dagger$

(Mean values with their standard errors of least square means for eight goats)

\begin{tabular}{|c|c|c|c|c|c|c|}
\hline \multirow[b]{2}{*}{ Component } & \multicolumn{3}{|c|}{ Control } & \multicolumn{3}{|c|}{ Food deprivation } \\
\hline & $\begin{array}{l}\mathrm{KCl} \\
\text { goats }\end{array}$ & $\begin{array}{l}\text { Mannitol } \\
\text { goats }\end{array}$ & $\mathrm{SE}$ & $\begin{array}{l}\mathrm{KCl} \\
\text { goats }\end{array}$ & $\begin{array}{c}\text { Mannitol } \\
\text { goats }\end{array}$ & $\mathrm{SE}$ \\
\hline $\mathrm{Na}$ & 27 & 22 & $13 \cdot 6$ & $110^{* *}$ & 45 & $9 \cdot 7$ \\
\hline $\mathrm{K}$ & 390 & 355 & $31 \cdot 1$ & 299 & $118^{* *}$ & $30 \cdot 1$ \\
\hline $\mathrm{Cl}$ & 80 & 74 & $18 \cdot 4$ & $290 * *$ & 32 & $16 \cdot 7$ \\
\hline
\end{tabular}

Mean values (day 2, 08.00 hours - day 3,08.00 hours) were significantly different from the corresponding control values (day 1, 08.00 hours - day 2, 08.00 hours): ** $P<0.01$.

$\dagger$ For details of procedures, see Fig. 1 and p. 212.

Table 2. Effects of food deprivation in combination with intrarumen loads of mannitol or potassium chloride on plasma concentrations of sodium $(m M)$, potassium $(m M)$ and chloride $(m M)$, plasma osmolality (mosmol $/ \mathrm{kg}$ ) and total plasma protein $(P P ; \mathrm{g} / \mathrm{l})$ in goats $\dagger$

(Mean values with their standard errors of least square means for eight goats)

\begin{tabular}{|c|c|c|c|c|c|c|}
\hline \multirow[b]{2}{*}{ Component } & \multicolumn{3}{|c|}{ Control } & \multicolumn{3}{|c|}{ Food deprivation } \\
\hline & $\begin{array}{l}\mathrm{KCl} \\
\text { goats }\end{array}$ & $\begin{array}{l}\text { Mannitol } \\
\text { goats }\end{array}$ & $\mathrm{SE}$ & $\begin{array}{c}\mathrm{KCl} \\
\text { goats }\end{array}$ & $\begin{array}{l}\text { Mannitol } \\
\text { goats }\end{array}$ & $\mathrm{SE}$ \\
\hline $\mathrm{Na}$ & 145 & 144 & 0.4 & 144 & $140^{* * *}$ & $0 \cdot 3$ \\
\hline $\mathrm{K}$ & 3.6 & 3.8 & $0 \cdot 10$ & $4 \cdot 4^{*}$ & $3 \cdot 6^{*}$ & $0 \cdot 14$ \\
\hline $\mathrm{Cl}$ & 107 & 105 & $1 \cdot 0$ & 107 & $100^{* * *}$ & 0.4 \\
\hline Osmolality & 299 & 298 & $1 \cdot 9$ & 298 & $292^{* *}$ & $0 \cdot 4$ \\
\hline PP & 64 & 65 & 0.7 & 66 & 65 & $1 \cdot 3$ \\
\hline
\end{tabular}

Mean values after $26 \mathrm{~h}$ food deprivation (day 3, 10.00 hours) were significantly different from corresponding control values (day $3,10.00$ hours): $* P<0.05, * * P<0.01, * * * P<0.001$.

$\dagger$ For details of procedures, see Fig. 1. and p. 212.

The PRA on day 1 (control values) were 0.09 and 0.07 pkat $/ 1$ for $\mathrm{KCl}$ goats and mannitol goats respectively (SE 0.050). On day 3 at 10.00 hours, PRA had decreased to $0.01 \mathrm{pkat} / 1$ for $\mathrm{KCl}$ goats $(P<0.01, \mathrm{KCl} v$. control values), whereas it had increased to $0.11 \mathrm{pkat} / 1$ for mannitol goats $(P<0.05$; mannitol $v$. control values) (SE 0.011 ).

The PAC on day 1 (control value) was $149 \mathrm{pm}$ for $\mathrm{KCl}$ goats and $111 \mathrm{pm}$ for mannitol goats (SE 58.1). The corresponding values on day 3 at 10.00 hours were 184 and $127 \mathrm{pm}$ (SE 75.6; not significant when compared with control values).

\section{Effects of an intrarumen load of water}

In $\mathrm{KCl}$ goats the plasma $\mathrm{K}$ concentration was significantly elevated both before and after the water load, while none of the other variables was significantly altered (Fig. 2). In the mannitol goats the plasma $\mathrm{Na}, \mathrm{Cl}$ and $\mathrm{K}$ concentrations and plasma osmolality which were reduced by food deprivation, remained at a lowered level $60 \mathrm{~min}$ after the water load (Fig. 2). The PP was not affected by the water load in either of the two treatments. The rate of TOH transfer from rumen to plasma after the water load was $2.3(\mathrm{SE} 0.3) \% / \mathrm{min}$ in mannitol goats, and 1.7 (SE 0.3$) \% / \mathrm{min}$ in $\mathrm{KCl}$ goats. The difference between treatments was not significant. 

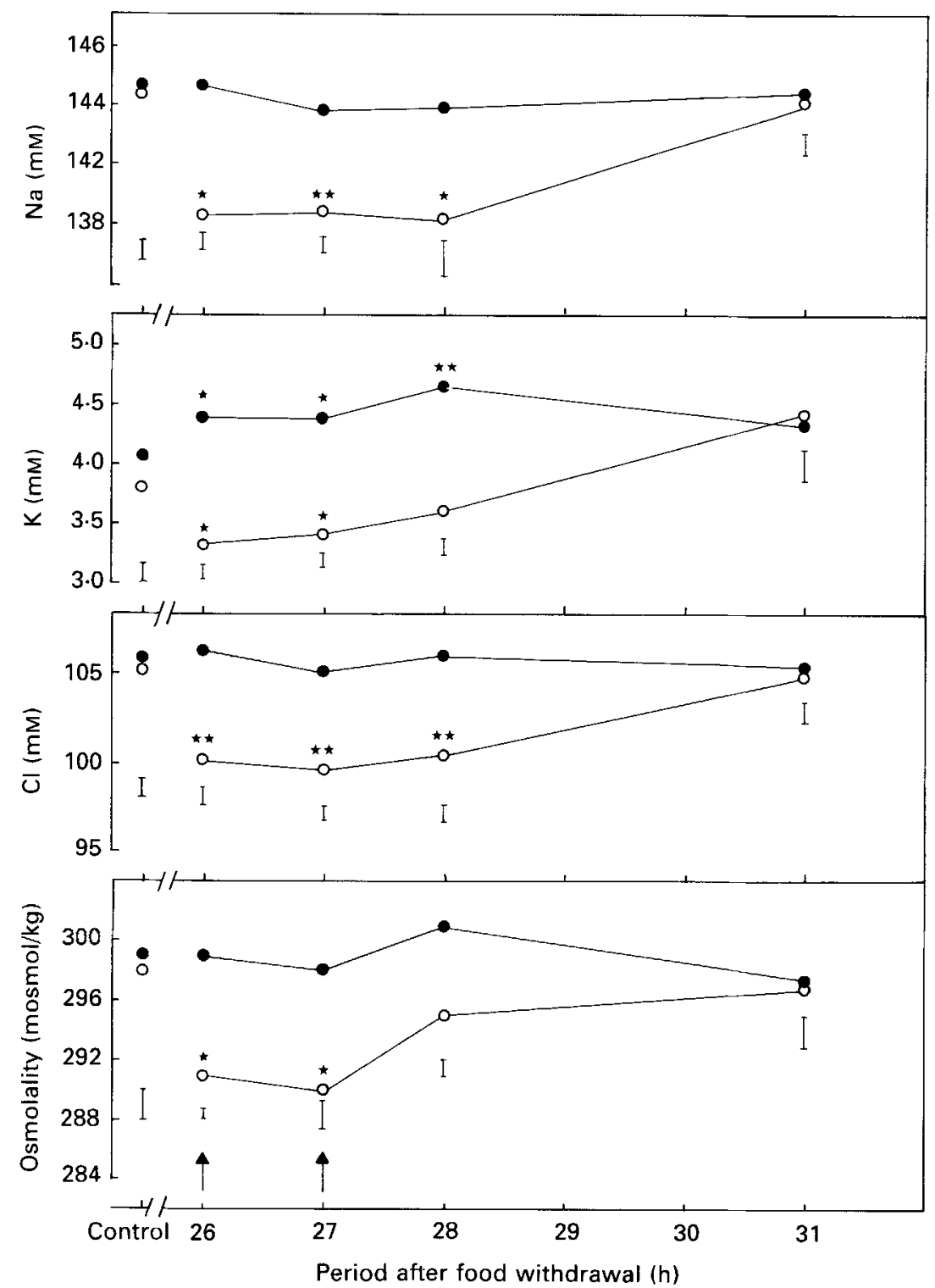

Fig. 2. The plasma concentration of sodium, potassium and chloride, and osmolality in fed goats (control), and in food-deprived goats which had been given either $\mathrm{KCl}(\odot)$ or mannitol $(O)$ at their regular feeding times. First arrow indicates an intrarumen load of water; second arrow indicates an intrarumen load of $\mathbf{K C l}$. Mean values were significantly different from control values by analysis of variance $(n 4)$ : ${ }^{*} P<0 \cdot 05,{ }^{* *} P<0 \cdot 01$.

\section{Effects of the extra $\mathrm{KCl}$ load}

In $\mathrm{KCl}$ goats the extra $\mathrm{KCl}$ load did not affect the plasma $\mathrm{Na}$ and $\mathrm{Cl}$ concentrations, the osmolality or the PP, but the plasma $\mathrm{K}$ concentration increased. In mannitol goats given a $\mathrm{KCl}$ load the plasma $\mathrm{Na}$ and $\mathrm{Cl}$ concentrations remained lowered, compared with control values $60 \mathrm{~min}$ after the load, while the plasma $\mathrm{K}$ concentration and osmolality increased towards the control values (Fig. 2). The PP dropped from 65 to $61 \mathrm{~g} / 1$ (SE $1 \cdot 1 ; P<0.05$ ).

Plasma $\mathrm{Na}, \mathrm{Cl}$ and $\mathrm{K}$ concentrations, and the plasma osmolality were all close to the 
control values $4 \mathrm{~h}$ after the extra $\mathrm{KCl}$ load with both treatments (Fig. 2). By then PP still did not significantly deviate from the control level in $\mathrm{KCl}$ goats, but had decreased to $59 \mathrm{~g} / 1$ (SE $1.5 ; P<0.05$ mannitol $v$. control values) in mannitol goats.

\section{DISCUSSION}

The results of the present study indicate that the concentration of plasma electrolytes and the plasma osmolality decreased in mannitol goats in a similar way to that reported with food-deprived goats and sheep receiving no treatment (Dahlborn \& Karlberg, 1986; Holtenius \& Dahlborn, $1990 a, b$ ). Mannitol has been used extensively to raise the osmolality of rumen fluid in absorption studies (Warner \& Stacy, 1977; Gäbel et al. 1987), and there appears to be no evidence of a direct influence of mannitol on electrolyte absorption. When the goats were supplemented with $\mathrm{KCl}$ during the food-deprivation period they maintained their plasma osmolality and plasma concentration of $\mathrm{Na}$ and $\mathrm{K}$ at the control level, and the plasma $\mathrm{K}$ concentration increased. These results suggest that the absorption of $\mathrm{Na}, \mathrm{K}$ and $\mathrm{Cl}$ from the rumen of food-deprived goats is increased by intrarumen loads of $\mathrm{KCl}$. In contrast to our findings, Rabinowitz et al. (1988) did not find any increased plasma $\mathrm{K}$ concentration in sheep in which one meal was replaced by an intrarumen infusion of $\mathrm{KCl}$. One explanation for the different results may be that three meals were replaced by $\mathrm{KCl}$ solutions in the present study.

The transport of $\mathrm{Na}$ and $\mathrm{Cl}$ across the rumen epithelium appears to be coupled over a wide range of physiological Na concentrations (Martens \& Blume, 1987). Thus, it is difficult to distinguish the roles of $\mathrm{K}$ and $\mathrm{Cl}$ in maintaining the electrolyte concentration during food deprivation in the present study. It has previously been observed that oral $\mathrm{NaCl}$ supplementation cannot maintain the plasma osmolality and plasma $\mathrm{Na}$ concentration of food-deprived goats (Dahlborn, 1987). Suttle \& Field (1967) have shown that fed sheep supplemented with $27 \mathrm{~g} \mathrm{~K}$ given as $\mathrm{KCl}$ or potassium acetate increased the urinary $\mathrm{Na}$ excretion. A similar increase in the urinary $\mathrm{Na}$ excretion due to intrarumen $\mathrm{KCl}$ loading has been observed in fed dik-dik antelopes (Rhynchotragus kirkii) (Rugangazi \& Maloiy, 1988). This could be explained by the fact that intrarumen $\mathrm{K}$ supplementation stimulates absorption of $\mathrm{Na}$ from the rumen (Scott, 1967;' Martens \& Hammer, 1981), and the enhanced absorption in turn increases the renal $\mathrm{Na}$ excretion. This, together with the results presented here, suggest that the rumen fluid $\mathrm{K}$ concentration is one important factor for the maintenance of plasma osmolality and plasma $\mathrm{Na}$ concentration during fasting. However, these in vivo studies do not agree with in vitro work in which increased $\mathrm{K}$ concentration on the lumen side of the rumen epithelium did not enhance $\mathrm{Na}$ absorption (Strozyk, 1987; Martens \& Gäbel, 1988). Therefore, Martens \& Gäbel (1988) suggested that lumen K could have an effect in vivo on blood flow or nervous activity, or both, with secondary effects on $\mathrm{Na}$ transport. However, the present results do not give support for changes in subepithelial blood flow as a cause for changes in $\mathrm{Na}$ transport since there was no significant difference in $\mathrm{TOH}$ clearance from the rumen between $\mathrm{KCl}$ goats and mannitol goats. The TOH clearance is correlated to rumen subepithelial blood flow (Dobson, 1979). It is thus not likely that the higher plasma $\mathrm{Na}$ concentration in $\mathrm{KCl}$-treated animals in the present study could be explained by enhanced rumen subepithelial blood flow.

In the present study the $\mathrm{KCl}$ goats increased both their $\mathrm{Na}$ and $\mathrm{Cl}$ excretions during food deprivation, although they did not receive any Na during the deprivation period. The result could scarcely be explained by increased $\mathrm{K}$ intake, since the amount given corresponded to the regular intake of $\mathrm{K}$. Therefore it appears more likely that in the present study renal excretion of $\mathrm{Cl}$ in the $\mathrm{KCl}$-treated animals brought about the increased $\mathrm{Na}$ excretion observed. 
The PP did not change during food deprivation in the present study, indicating that the plasma volume was unchanged. Previous studies have shown that food deprivation in goats leads to decreased plasma volume (Dahlborn \& Karlberg, 1986). Thus, it seems that water absorption from the gastrointestinal tract was maintained during food deprivation by intrarumen loads of both mannitol and $\mathrm{KCl}$. Intrarumen addition of $\mathrm{K}$ seems to stimulate rumen $\mathrm{Na}$ absorption in food-deprived goats, and water is mainly absorbed from the gastrointestinal tract secondary to $\mathrm{Na}$ absorption (Stevens, 1988). Thus, the unchanged plasma volume in $\mathrm{KCl}$ goats during food deprivation could be explained by the stimulation of $\mathrm{Na}$ absorption. In support of this explanation is the fact that when the mannitol goats were given an intrarumen load of $\mathrm{KCl}$, the plasma volume increased in combination with increasing plasma $\mathrm{Na}$ concentration. However, mannitol goats also maintained their plasma volume during food deprivation. This effect of the intrarumen loads of mannitol is difficult to explain.

The lowered PRA in KCl-supplemented goats is interesting. Goats drinking a $\mathrm{NaCl}$ solution during food deprivation also seem to react with decreased PRA, although the effect has not been statistically tested (Dahlborn, 1987). Kirchner et al. (1978) proposed that inhibition of the renin release in $\mathrm{NaCl}$-loaded rats is related to $\mathrm{Cl}$ transport in the thick ascending loop of Henle. A similar conclusion was drawn from studies with human subjects (Julian et al. 1982). The results obtained in the present study indirectly indicate that an intrarenal $\mathrm{Cl}$ load could be an effective suppressor of the renin release also in ruminants.

Increasing plasma $\mathrm{K}$ concentration, decreasing plasma $\mathrm{Na}$ concentration and activation of the renin-angiotensin system are important factors stimulating the plasma aldosterone secretion in ruminants (for review, see Denton, 1982). The increased plasma $K$ concentration in $\mathrm{KCl}$ goats in the present study could thus be expected to give rise to elevated secretion of aldosterone. However, in the goats the PRA was suppressed which in turn could be expected to decrease the PAC. Thus, the net effect on the PAC was probably small.

In mannitol goats PRA increased, and the plasma Na concentration was lowered, but PAC was unaffected. This might be explained by the fact that the plasma concentration of $\mathrm{K}$ decreased.

When the mannitol goats were given an intrarumen dose of $\mathrm{KCl}$ the plasma concentrations of $\mathrm{Na}, \mathrm{K}$ and $\mathrm{Cl}$ as well as the plasma osmolality rose, and had returned to prestarvation levels within $4 \mathrm{~h}$. Food-deprived goats receiving 3 litres water, and then subjected to a similar blood sampling procedure as in the present study, did not restore their plasma $\mathrm{Na}$ concentration to prestarvation levels after the load (Holtenius \& Dahlborn, 1990a). Neither the plasma K concentration nor plasma osmolality returned to their prestarvation values ( $K$. Holtenius and $K$. Dahlborn, unpublished results). It is therefore reasonable to assume that intrarumen loads of $\mathrm{KCl}$ can not only maintain plasma electrolyte concentration during food deprivation but can also restore the plasma electrolyte concentration in goats that had been food deprived for $27 \mathrm{~h}$.

In conclusion, the results presented here indicate that dietary $\mathrm{K}$ is an important factor in the rumen absorption of $\mathrm{Na}$, and that the hyponatraemia which develops during food deprivation in ruminants could be explained by diminished $\mathrm{K}$ intake. Further investigations are needed in order to clarify the mechanism of K-stimulated $\mathrm{Na}$ absorption from the rumen.

This work was supported by the Swedish Council for Forestry and Agricultural Research (Project nos D254 and Y9:4). 


\section{REFERENCES}

Dahlborn, K. (1987). Fluid balance in food-deprived goats drinking saline. Quarterly Journal of Experimental Physiology 72, 593-600.

Dahlborn, K. \& Karlberg, B. E. (1986). Fluid balance during food deprivation and after loads of water or isotonic saline in lactating and anoestral goats. Quarterly Journal of Experimental Physiology 71, 223-233.

Denton, D. (1982). The hunger for salt. An Antropological, Physiological and Medical Analysis, pp. $147-167$. Berlin, Heidelberg and New York: Springer-Verlag.

Dobson, A. (1959). Active transport through the epithelium of the reticulo-rumen sac. Journal of Physiology 146, 235-251.

Dobson, A. (1979). Choice of models relating tritiated water absorption to subepithelial blood flow in the rumen of sheep. Journal of Physiology 297, 111-121.

Gäbel, G., Suendermann, M. \& Martens, H. (1987). The influence of osmotic pressure, lactic acid and $\mathrm{pH}$ on ion and fluid absorption from the washed and temporarily isolated reticulo-rumen of sheep. Journal of Veterinary Medicine A34, 220-226.

Holtenius, K. \& Björnhag, G. (1989). The significance of water absorption and fibre digestion in the omasum of sheep, goats and cattle. Comparative Biochemistry and Physiology 94A, 105-109.

Holtenius, K. \& Dahlborn, K. (1990a). Effects of intraruminal loads of volatile fatty acids, saline, and water in the food deprived goat. Small Ruminant Research (In the Press.)

Holtenius, K. \& Dahlborn, K. (1990b). Water and sodium movements across the ruminal epithelium in fed and food deprived sheep. Experimental Physiology 75 57-67.

Julian, B. A., Galla, J. H., Guthrie, G. P. \& Kotchen, T. A. (1982). Renin and aldosterone responses to short term $\mathrm{NaCl}$ or $\mathrm{NaHCO}_{3}$ loading in man. Journal of Laboratory and Clinical Medicine 100, 261-268.

Kirchner, K. A., Kotchen, T. A., Galla, J. H. \& Luke, R. G. (1978). Importance of chloride for acute inhibition of renin by sodium chloride. American Journal of Physiology 235, F444-F450.

McDougall, E. 1. (1948). The composition and output of sheep's saliva. Biochemical Journal 43, $99 \cdots 109$.

McKenzie, J. K. \& Clements, J. A. (1974). Simplified radioimmunoassay for serum aldosterone utilizing increased antibody specificity. Journal of Endocrinology and Metabolism 38, 622-627.

Martens, H. \& Blume, I. (1987). Studies on the absorption of sodium and chloride from the rumen of sheep. Comparative Biochemistry and Physiology 86A, 653-656

Martens, H. \& Gäbel, G. (1988). Transport of $\mathrm{Na}$ and $\mathrm{Cl}$ across the epithelium of ruminant forestomachs: Rumen and omasum. A review. Comparative Biochemistry and Physiology 90A, 569-575

Martens, H. \& Hammer, U. (1981). Resorption von Natrium und Magnesium aus dem vorübergehend isolierten Pansen von Schafen während intravenöser Infusion von Aldosteron. Dettsche tierärztliche Wochenschrift $\mathbf{8 8}$. 404-407

Rabinowitz, L., Green, D. M., Sarason, R. L. \& Yamauchi, H. (1988). Homeostatic potassium excretion in fed and fasted sheep. American Journal of Physiology 254, R357-R380.

Rugangazi, B. M. \& Maloiy, G. M. (1988). Studies on renal excretion of potassium in the dik-dik antelope Comparative Biochemistry and Physiology 90A, 121-126.

Scott, D. (1967). The effects of potassium supplements upon the absorption of potassium and sodium from the sheep rumen. Quarterly Joumal of Experimental Physiology 52, 382-391.

Stevens, C. E. (1988). Comparative Physiology of the Vertebrate Digestive System. Cambridge: Cambridge University Press.

Strozyk, B. M. (1987). Untersuchungen über den Transport von Natrium durch das isolierte Pansenepithel von Schafen: Hinweise für einen $\mathrm{Na} / \mathrm{H}$ Austausch in der luminalen Membran. $\mathrm{PhD}$ Thesis, Tierärztlichen Hochschule Hannover.

Suttle, N. F. \& Field, A. C. (1967). Studies on magnesium in ruminant nutrition. British Journal of Nutrition 21, 819-831.

Warner, A. C. \& Stacy, B. D. (1977). Infuence of ruminal and plasma osmotic pressure on saliva secretion in sheep. Quarterly Journal of Experimental Physiology 62, 133-142. 